\title{
ПЕНСИОНЕРЫ НА РОССИЙСКОМ РЫНКЕ ТРУДА: ТЕНДЕНЦИИ ЭКОНОМИЧЕСКОЙ АКТИВНОСТИ ЛЮДЕЙ ПЕНСИОННОГО ВОЗРАСТА *
}

\author{
ЮЛИЯ СОНИНА, МАРИНА КОЛОСНИЦЫНА
}

\begin{abstract}
Старение населения заставляет исследователей всего мира все глубже изучать вопросы экономической активности пенсионеров. В России в последние годы занятость людей пенсионного возраста значительно возросла при практически неизменном значении этого показателя для населения в основном трудоспособном возрасте. Этот факт требует объяснений. Выявить основные тенденции занятости пенсионеров позволяет анализ микроэкономических данных Российского мониторинга экономического положения и здоровья населения (РМЭЗ) НИУ ВШЭ.

В статье на основе данных Росстата и РМЭЗ НИУ ВШЭ прослеживается динамика занятости людей после достижения стандартного пенсионного возраста (55 лет для женщин и 60 - для мужчин) до 70 лет. Показано, что в 2002-2013 г2. возросла занятость пенсионеров всех возрастов, но по абсолютному приросту в уровне занятости лидируют женщины в возрасте 60-64 года. В статье также исследуются основные характеристики занятости пенсионеров. На основе анализа микроэкономических данных РМЭЗ НИУ ВШЭ показано, что среди всех работающих пенсионеров за рассматриваемый период выросла доля тех, кто работает в образовании, здравоохранении, науке, ЖКХ, МВД и ВПК (секторах экономики с преобладающей ролью государства). Поэтому основные траектории занятости в пенсионном возрасте - либо продолжение работь в этих сферах деятельности, либо смена работь, зачастую предполагающая занятость на должностной позиции, не требующей высокого уровня квалификаџии и офищиального оформления трудоустройства. В отличие от развитых стран, в России наблюдавиийся за последние годы рост экономической активности пенсионеров не был связан с повышением гибкости рынка труда. Ни доля самозанятых, ни доля частично занятых пенсионеров за рассматриваемый период не выросли.
\end{abstract}

Ключевые слова: пенсионеры, пожилье, занятость, экономическая активность, Россия.

\section{ВВЕДЕНИЕ}

В условиях старения населения потенциальным резервом увеличения численности занятых выступает население в пенсионном возрасте. В этой связи стимулирование трудовой активности пенсионеров становится важным направлением социально-экономической политики многих стран. До недавнего времени в России отсутствовала специальная политика, стимулирующая занятость пенсионеров. Основной принцип участия государства в этой сфере можно было охарактеризовать как принцип невмешательства.

\footnotetext{
СОНИНА ЮЛИЯ ВЛАДИМИРОВНА, НАЦИОНАЛЬНЫЙ ИССЛЕДОВАТЕЛЬСКИЙ УНИВЕРСИТЕТ «ВЫСШАЯ ШКОЛА ЭКОНОМИКИ», РосСИЯ. E-mail: juliasonina@hse.ru КОЛОСНИЦЫНА МАРИНА ГРИГОРЬЕВНА, НАЦИОНАЛЬНЫЙ ИССЛЕДОВАТЕЛЬСКИЙ УНИВЕРСИТЕТ «ВЫСШАЯ ШКОЛА ЭКОНОМИКИ», РОССИЯ.

СТАТЬЯ ПОСТУПИЛА В РЕДАКЦИЮ В МАРТЕ 2015 Г.

* СТАТЬЯ ПОДГОТОВЛЕНА В РАМКАХ ПРОЕКТА ПРОГРАММЫ ФУНДАМЕНТАЛЬНЫХ ИССЛЕДОВАНИЙ НИУ ВШЭ «АНАЛИЗ ПОТЕНЦИАЛА ПОЖИЛЫХ ЛЮДЕЙ И СОЦИАЛЬНО-ЭКОНОМИЧЕСКИХ ФАКТОРОВ АКТИВНОГО ДОЛГОЛЕТИЯ В ЦЕЛЯХ ГОСУДАРСТВЕННОЙ ПОЛИТИКИ» (2015 г.).
} 
Некоторые подвижки в этой области появились лишь в последние годы. В 2013 г. региональным органам службы занятости было предоставлено право направлять пенсионеров, желающих возобновить трудовую деятельность, на программы профессионального обучения и дополнительного профессионального образования [Федеральный закон... 2013]. А с 2015 г. вступила в силу новая «пенсионная формула», позволяющая пенсионерам увеличить размер пенсии при более позднем (в сравнении со стандартным) возрасте обращения за пенсией.

Однако при разработке программ обучения не обойтись без анализа тех реальных возможностей, которые предлагает российским пенсионерам рынок труда. Необходимо понимать, в каких сферах деятельности и профессиях занятость пенсионеров возможна и наиболее распространена. Кроме того, стимулирование граждан в рамках новой пенсионной системы к отсрочке оформления пенсии не обязательно автоматически приведет к увеличению занятости пожилых людей - на вероятный рост предложения труда пенсионеров должен найтись соответствующий спрос. Тем не менее фактически наблюдаемый рост занятости пенсионеров в последние десятилетия позволяет говорить о том, что рост спроса исключать не стоит. Но будет он повсеместным или сосредоточенным в определенных видах деятельности? Анализ произошедших изменений в занятости пенсионеров и выявление тех видов деятельности и профессий, которые стали реципиентами дополнительного притока работающих пенсионеров, поможет лучше понять существующие перспективы и проблемы занятости пенсионеров.

Таким образом, цель данной статьи - выявление остальные тенденции занятости пенсионеров в российской экономике. Это позволит понять как причины роста занятости пенсионеров в последние годы, так и возможные изменения в ближайшее время, и предложить адекватные меры государственной политики стимулирования экономической активности пожилых.

\section{ХАРАКТЕРИСТИКА ДАННЫХ}

Для анализа экономической активности лиц пенсионного возраста в России мы использовали агрегированные данные Росстата (регулярные обследования населения по проблемам занятости - ОНП ${ }^{1}$ ) и данные Российского мониторинга экономического положения и здоровья населения (РМЭЗ) НИУ ВШЭ². Первый источник предоставляет ежегодные данные с 1992 по 2013 г., второй - с 1994 по 2013 г. (на момент написания статьи) с перерывами в 1997 и 1999 г. Учитывая пробелы в имеющихся данных, а также непростую экономическую ситуацию, связанную как с трансформационным восстановлением экономики после распада СССР, так и финансовым кризисом 1998 г., а также ограничения на доходы работающих пенсионеров, действовавшие в 1998-2001 гг., мы решили ограничиться данными 2002-2013 гг. Этот период является однородным с точки

\footnotetext{
${ }^{1}$ выборочных обследований населения по проблемам занятости (обследований рабочей силы)

${ }^{2}$ «Российский мониторинг экономического положения и здоровья населения НИУ-ВШЭ (RLMS-HSE)», проводимый Национальным исследовательским университетом "Высшая школа экономики" и ЗАО «Демоскоп» при участии Центра народонаселения Университета Северной Каролины в Чапел Хилл и Института социологии PAH. URL: http://www.cpc.unc.edu/projects/rlms и http://www.hse.ru/rlms.
} 
зрения институциональных рамок-основные характеристики пенсионной системы в данный период не менялись. С 2002 г. российские пенсионеры имеют право на получение полного размера пенсии вне зависимости от статуса занятости. В то же время не существует законодательного установленного возраста прекращения трудовой деятельности, за исключением ряда нормативно-правовых актов, допускающих такие ограничения для государственной службы [Федеральный закон... 1995], военнослужащих и служащих правоохранительных органов.

Данные ОНПЗ показывают, что в России экономическая активность пожилых увеличилась. За 2002-2013 гг. этот показатель для населения в возрасте от 50 до 54 лет вырос с 82,7 до 85,6\% (+2,9 п.п.), в возрасте от 55 до 59 лет - с 58,7\% до 63,9\% (+5,2 п.п.), в возрасте старше 60 лет - с 17 до 21,6\% (+4,6 п.п.). Рост уровня экономической активности в названных возрастных группах происходил при практически неизменном значении этого показателя для населения в возрасте 25-44 года.

К сожалению, официальные данные Росстата не позволяют увидеть динамику экономической активности пенсионеров в разных возрастах после 60 лет. Максимум, что освещают агрегированные данные регулярных обследований населения по проблемам занятости, - уровень участия в рабочей силе женщин в первые пять лет после выхода на пенсию. Для мужчин весь пенсионный период официальной статистикой непредусмотрительно объединен в один интервал 60-72 года (согласно принятой методологии, опросы проводятся для населения не старше 72 лет), что осложняет задачу анализа их поведения после достижения официального пенсионного возраста.

Избежать недостатков официальной статистики позволяют данные РМЭЗ НИУ ВШЭ. Являясь результатом ежегодных лонгитюдных обследований домохозяйств, данные РМЭЗ предоставляют возможность анализа многочисленных аспектов жизнедеятельности индивидов разных возрастов. В этом смысле РМЭЗ предоставляет альтернативные государственной статистике репрезентативные микроэкономические данные, позволяющие проанализировать структуру и динамику занятости людей после достижения ими официального пенсионного возраста.

Для описания положения пенсионеров на российском рынке труда в настоящей статье используются репрезентативные данные РМЭЗ за 2002 -2013 гг. Объектом исследования стали индивиды, достигшие стандартного возраста выхода на пенсию (мужчины - 60 лет, женщины - 55 лет) и младше 70 лет $^{3}$.

Половозрастная структура населения пенсионного возраста, представленная данными ОНПЗ Росстата и РМЭЗ НИУ ВШЭ, несколько различается, однако различия не масштабны (таблица 1). Оба обследования в целом фиксируют рост доли женщин среди пожилого населения при переходе к более старшим возрастным группам.

\footnotetext{
${ }^{3}$ Уровень занятости пожилых людей в возрасте 70-72 года не превышает 20\%. Учитывая немногочисленность представителей данной когорты в РМЭЗ, устойчивость результатов трудно обеспечить. Это обусловило наш отказ от детального рассмотрения данной подгруппы пожилых работников, кроме как для целей сравнения данных ОНПЗ и РМЭЗ НИУ ВШЭ в таблицах 1 и 2.
} 
Таблица 1. Сравнение половозрастных структур населения по данным РМЭЗ НИУ ВШЭ и ОНПЗ Росстата, доля женщин, \% от соответствующей возрастной группы

\begin{tabular}{c|c|c|c|c|c|c|c|c}
\hline \multirow{2}{*}{ Год } & \multicolumn{2}{|c|}{ Женщины, 55-59 лет } & \multicolumn{2}{c|}{ Женщины, 60-64 года } & \multicolumn{2}{c|}{ Женщины, 65-69 лет } & \multicolumn{2}{c}{ Женщины, 70-72 года } \\
\cline { 2 - 9 } & Росстат & РМЭ3 & Росстат & РМЭ3 & Росстат & РМЭ3 & Росстат & РМЭ3 \\
\hline 2002 & 55,8 & 60,4 & 59,3 & 62,8 & 61,5 & 63,7 & 64,5 & 64,5 \\
2005 & 56,1 & 60,7 & 59,5 & 58,2 & 62,5 & 67,6 & 64,8 & 67,9 \\
2010 & 56,6 & 59,4 & 58,6 & 62,5 & 62,7 & 64,4 & 65,8 & 69,7 \\
2011 & 56,6 & 59,7 & 58,7 & 63,4 & 61,9 & 65,5 & 65,9 & 66,0 \\
2012 & 56,4 & 61,0 & 58,8 & 61,1 & 61,4 & 66,5 & 65,9 & 68,4 \\
2013 & 56,3 & 59,2 & 58,8 & 63,7 & 61,4 & 65,4 & 65,8 & 67,5 \\
\hline
\end{tabular}

Источники: [Госкомстат 2002, Росстат 2014], РМЭЗ НИУ ВШЭ.

Основные показатели, характеризующие экономическую активность пенсионеров на основе данных ОНПЗ Росстата и РМЭЗ НИУ ВШЭ, представлены в таблице 2.

Таблица 2. Уровень экономической активности лиц в зависимости от возраста, \%

\begin{tabular}{l|c|c|c|c|c|c}
\hline \multirow{2}{*}{} & \multicolumn{2}{|c|}{ Мужчины, 60-72 лет } & \multicolumn{2}{c|}{ Женщины, 55-59 лет } & \multicolumn{2}{c}{ Женщины, 60-72 года } \\
\cline { 2 - 7 } & ОНП3 & РМЭ3 & ОНП3 & РМЭ3 & ОНП3 & РМЭ3 \\
\hline 2002 & 23,9 & 23,3 & 48,0 & 52,7 & 12,5 & 16,0 \\
2005 & 23,5 & 24,8 & 53,8 & 53,4 & 12,8 & 15,6 \\
2010 & 25,9 & 33,8 & 50,7 & 56,0 & 15,2 & 22,6 \\
2013 & 27,9 & 32,3 & 53,6 & 52,9 & 17,6 & 23,8 \\
Изменения, п.п. & $+4,0$ & $+9,0$ & $+5,6$ & $+0,2$ & $+5,1$ & $+7,8$ \\
\hline
\end{tabular}

Источники: РМЭЗ НИУ ВШЭ, [Госкомстат 2002, Росстат 2014].

Оценки изменения экономической активности лиц, достигших официального пенсионного возраста, полученные по данным ОНПЗ и РМЭЗ, немного различаются. Первые говорят и о более высоком уровне $(53,6 \%)$, и о большем росте $(+5,6$ п.п.) за 20022013 гг. экономической активности женщин 55-59 лет. Данные РМЭЗ также отдают лидерство в уровне экономической активности женщинам этой возрастной когорты (52,9\%), но за 2002-2013 гг. больший прирост в уровне экономической активности фиксируют для мужчин 60-72 лет (+9 п.п. до 32,3\%). Природа различий между данными РМЭЗ и ОНПЗ об уровне экономической активности обусловлена сложностями достижения одинаковой трактовки статуса занятости людей, имеющих случайные заработки или находящихся в неоплачиваемом отпуске. Немногочисленность и нераспространенность занятости среди респондентов РМЭЗ в возрасте 70-72 лет также может искажать полученные результаты. А отказ от рассмотрения этой немногочисленной когорты лишит нас сопоставимости с данными Росстата. Понимая такие недостатки, но добившись единой интерпретации занятости, безработицы и неактивности по остальным группам населения (более 90\%), а также ограничившись анализом данных по респондентам в возрасте до 70 лет, мы будем далее использовать данные РМЭЗ в качестве альтернативы данным ОНПЗ.

В РМЭЗ к занятым относились те, кто работал или имел приработки в течение последних 30 дней перед интервью, включая находящихся в оплачиваемом или неоплачиваемом отпуске (в случае занятости на этой или любой другой работе). Безработные определялись на основе ответов на вопросы о наличии работы, поиске работы и готовности к ней приступить. Если в течение последних 30 дней респондент не имел работы, искал работу и был готов к ней приступить, то он считался безработным. Уровень 
экономической активности по возрастным группам рассчитывался как доля экономически активных (занятых и безработных) в отношении к численности населения в данной возрастной группе; уровень занятости - как доля занятых в составе соответствующей возрастной группы.

\section{ДИНАМИКА ЗАНЯТОСТИ ПЕНСИОНЕРОВ}

В 2002-2013 гг. уровень экономической активности мужчин увеличивался в основном за счет роста их занятости в возрасте 65-69 лет. Занятость мужчин в возрасте 60-64 года не демонстрировала монотонной динамики (рисунок 1). Для нее были характерны рост занятости в период экономического роста и спад во время кризиса.

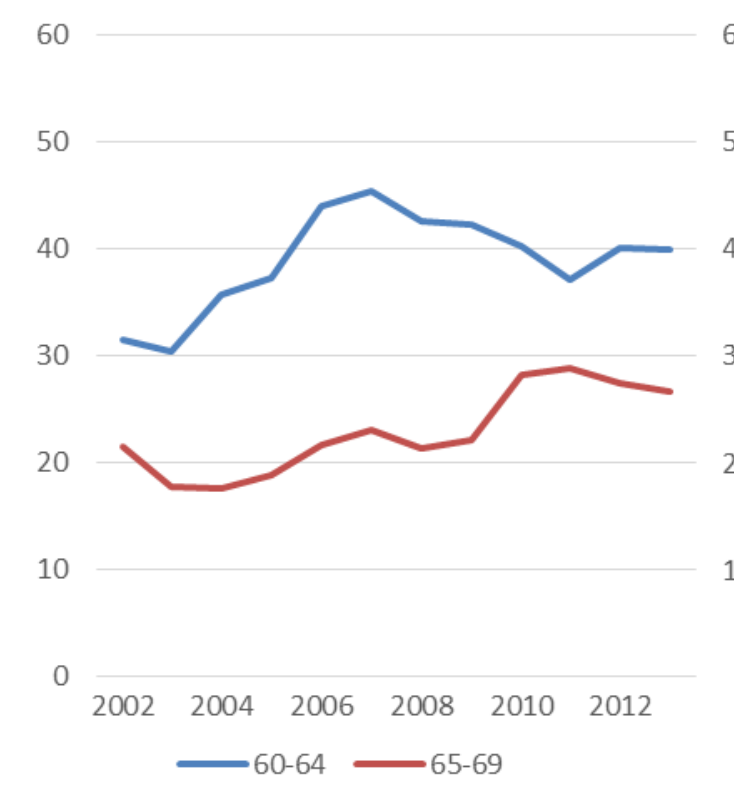

Рисунок 1. Динамика занятости мужчин, \%

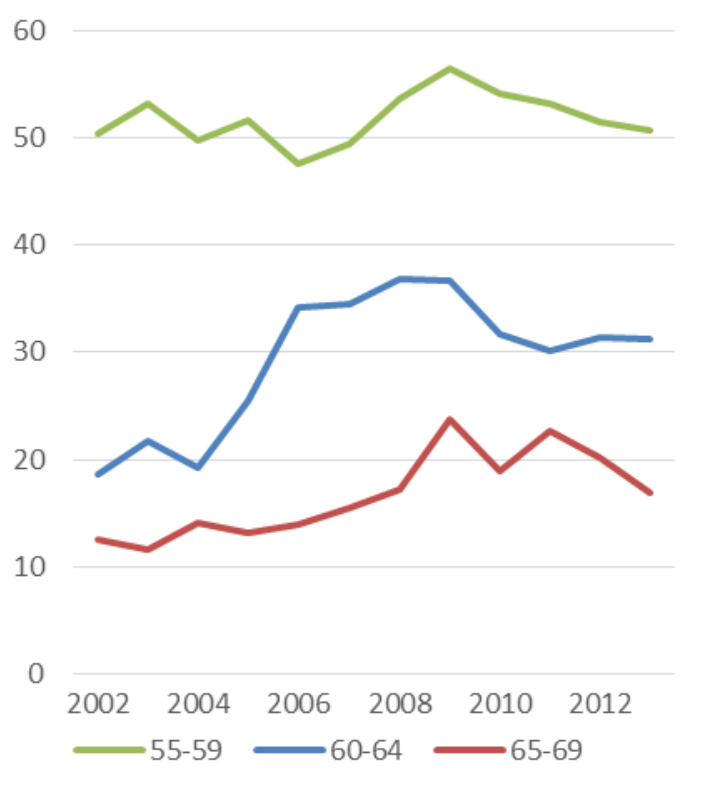

Рисунок 2. Динамика занятости женщин, \%

Источник: расчеты авторов по данным РМЭЗ НИУ ВШЭ

Занятость женщин также изменялась немонотонно (рисунок 2). Наиболее заметен рост занятости женщин в возрасте 55-59 и 65-69 лет в 2008-2009 гг. Мы не исключаем, что рост занятости женщин в этот период является проявлением эффекта «дополнительного работника». Как правило, это явление возникает в периоды роста безработицы - часть людей вступает на рынок труда, чтобы поддержать доход семьи, который мог уменьшиться из-за потери работы основным работником в семье. Экономический кризис 2008-2009 гг. сопровождался ростом безработицы с 6,2 до 8,3\%. В то же время занятость женщин в возрасте 55-59 и 65-69 лет выросла примерно на 7-8 п.п. По мере восстановления экономического роста и снижения уровня безработицы действие этого эффекта сходило на нет. Однако это только наша гипотеза, которая требует более детального анализа панельных данных за этот временной промежуток, и в данной статье ее подтверждение не проводится.

Женщины в возрасте 60-64 года, напротив, больше всего «выиграли» в период бурного экономического роста, открывшего больше возможностей для их занятости. 
В целом за 2002-2013 гг. наибольший прирост занятости среди лиц пенсионного возраста продемонстрировали женщины 60-64 лет (+12,6 п.п.) и мужчины 60-64 лет (+8,6 п.п.). Можно предположить, что улучшение состояния здоровья, экономический рост 2000х годов и негативные демографические тренды позволили дольше оставаться экономически активными не только молодым пенсионерам, но и лицам, находящимся на пенсии дольше пяти лет. Рост экономической активности наблюдался во всех возрастных группах.

Наблюдаемая динамика роста вовлеченности пенсионеров в трудовую деятельность определяется рядом причин, действующих со стороны как спроса, так и предложения на рынке труда. Исследования объясняют рост экономической активности пенсионеров сокращением доли физического труда и смещением занятости в сторону интеллектуальных сфер деятельности [Малева, Синявская 2008: тема 5], улучшением их состояния здоровья и повышением уровня образования [Колосницына, Герасименко 2014]. Так, за 2000-2013 гг. доля пенсионеров, имеющих начальное профессиональное или среднее специальное образование, выросла в 1,3 раза, получивших высшее образование - в 1,6 раза. В то же время доля пожилых людей, оценивающих свое здоровье как плохое и очень плохое, за 1994-2012 гг. сократилась с 40 до 30\% [Колосницына, Герасименко 2014].

\section{СТРУКТУРА ЗАНЯТОСТИ ПО ВИДАМ ДЕЯТЕЛЬНОСТИ}

Структура занятости мужчин отчетливо меняется с возрастом ${ }^{4}$ (таблица 3 ). В основном трудоспособном возрасте (20-59 лет) их занятость сосредоточена в торговле $(16,3 \%)$, строительстве $(14,7 \%)$ и на транспорте $(13,8 \%)$. Мужчины пенсионного возраста преимущественно работают в ЖКХ $(13,8 \%)$, образовании $(10,8 \%)$, строительстве (8\%). Таким образом, среди возможных сфер деятельности наиболее привлекательными для занятости пенсионеров являются ЖКХ (изменение доли в отраслевой структуре занятости +9 п.п.), образование (+7,7 п.п.), здравоохранение (+4,6 п.п.), ВПК (+4,1 п.п.), наука (+3,7 п.п.).

Стоит отметить, что в течение последнего десятилетия приоритетные отрасли занятости мужчин в пенсионном возрасте менялись. Доля мужчин в возрасте 60-69 лет, занятых на предприятиях транспорта, гражданского машиностроения, в строительстве, $2004^{5}-2013$ гг. снижалась. Напротив, доля пенсионеров-мужчин, работающих в МВД, ВПК, ЖКХ, органах государственного управления, образовании, науке и сельском хозяйстве, значимо увеличилась (рисунок 3). В 2004 г. в этих отраслях было занято около 40\% экономически активных пенсионеров, перед кризисом 2008-2009 гг. доля снизилась до 30\%, но в 2013 г. в них было занято не менее 55\% экономически активных пенсионеров-мужчин.

\footnotetext{
${ }^{4}$ Отраслевая структура занятости также сильно различается и внутри трудоспособного возраста. Объединение всего трудоспособного населения в одну группу носит довольно условный характер.

${ }^{5}$ Сравнение начинается с 2004 г., так как до этого в РМЭЗ отсутствовала подобная информация.
} 


\section{Таблица 3. Структура занятости мужчин по видам деятельности в зависимости от} возраста, доля занятых, \%, 2013

\begin{tabular}{|c|c|c|c|c|c|c|c|c|c|c|c|c|c|c|c|}
\hline & 突 & 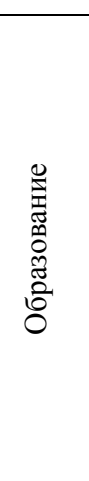 & 单 & 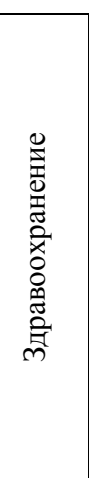 & 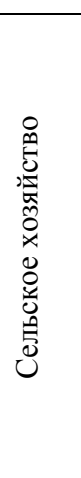 & 茎 & 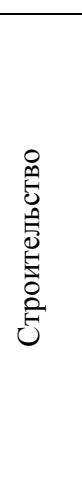 & 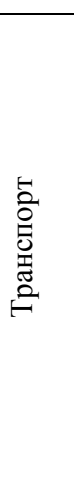 & $\stackrel{\tilde{q}}{\Sigma}$ & 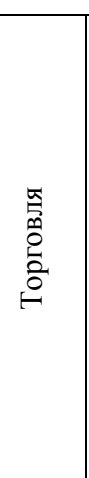 & 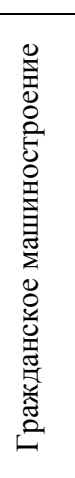 & 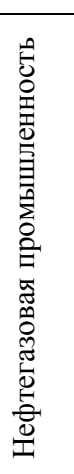 & 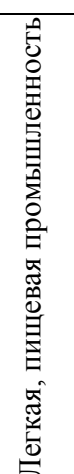 & 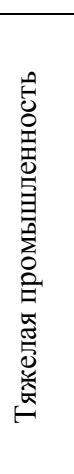 & 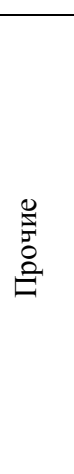 \\
\hline $25-59$ лет & 5,4 & 3,4 & 2,8 & 2,7 & 7,6 & 1,4 & 14,8 & 14,4 & 6,9 & 13,9 & 2,9 & 4,2 & 5,0 & 5,0 & 9,6 \\
\hline 60-69 лет & 13,8 & 10,8 & 6,6 & 7,0 & 7,1 & 5,4 & 8,0 & 7,6 & 5,9 & 6,0 & 3,9 & 2,3 & 2,8 & 5,0 & 7,8 \\
\hline $\begin{array}{l}\text { Изменение } \\
\text { доли, п.п. (+/-) }\end{array}$ & $+8,4$ & $+7,4$ & $+3,9$ & $+4,3$ & $-0,5$ & $+4,0$ & $-6,8$ & $-6,8$ & $-1,0$ & $-7,9$ & $+1,0$ & $-1,9$ & $-2,2$ & $-0,1$ & $-1,7$ \\
\hline
\end{tabular}

Источник: расчеты авторов по данным РМЭЗ НИУ ВШЭ.

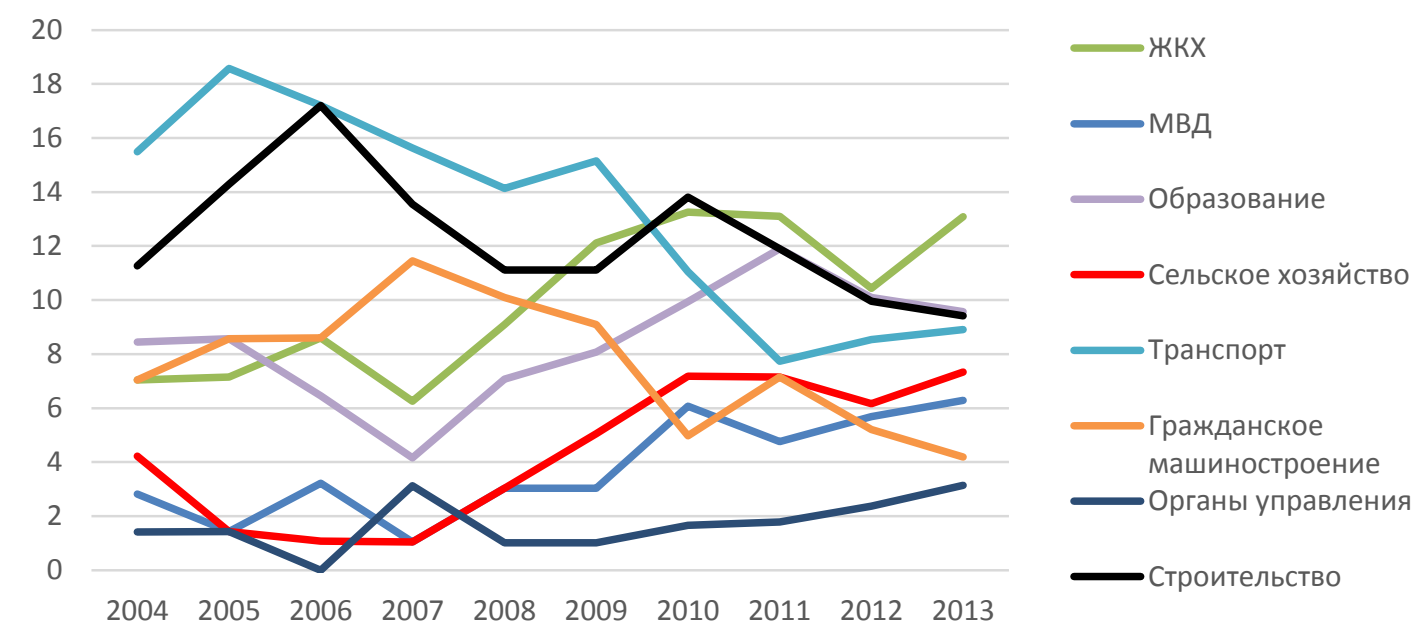

Рисунок 3. Структура занятости мужчин в возрасте 60-69 лет по видам деятельности, доля занятых, \%, 2004-2013

Источник: расчеты авторов по данным РМЭЗ НИУ ВШЭ.

Структура занятости женщин по видам деятельности в зависимости от возраста изменяется не столь сильно (таблица 4). И в основном трудоспособном, и в пенсионном возрасте большая часть женщин работает в торговле (28,9 и 14,8\% занятых соответственно), образовании $(14,1$ и $19,2 \%)$, здравоохранении $(10,7$ и 19,2\%), легкой и пищевой промышленности $(6,8 \%$ и $8,2 \%)$. Однако при переходе от основного трудоспособного возраста к пенсионному возрасту наибольший прирост доли в отраслевой структуре занятости демонстрируют здравоохранение (+8,5 п.п.), образование $(+5,1$ п.п), ЖКХ $(+4,1$ п.п.), наука (+3,9 п.п.). «Потери» несет торговля (-14,1 п.п.).

Структура занятости женщин пенсионного возраста также оставалась достаточно стабильной на протяжении последнего десятилетия (рисунок 4). Помимо кризисных 20082009 гг., временно повысивших число занятых пенсионеров-женщин в торговле, изменения отраслевой структуры занятости шли плавно. Доля женщин пенсионного возраста, 
работающих в органах управления, здравоохранении, образовании выросла за 2004-2013 гг. с 60 до $67 \%$.

Таблица 4. Структура занятости женщин по видам деятельности в зависимости от возраста, доля занятых, \%, 2013

\begin{tabular}{|c|c|c|c|c|c|c|c|c|c|c|c|c|c|c|}
\hline & 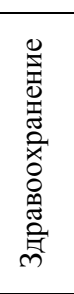 & 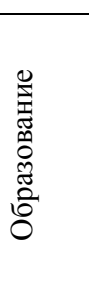 & 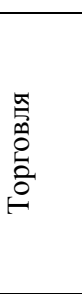 & 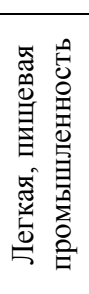 & 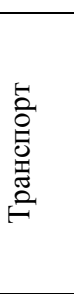 & 苮 & 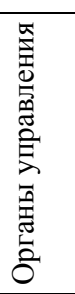 & 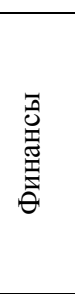 & $\frac{x}{0}$ & $\begin{array}{l}\mathbb{F} \\
\mathfrak{n}^{\mathfrak{n}}\end{array}$ & 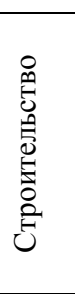 & 究 & 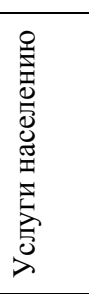 & 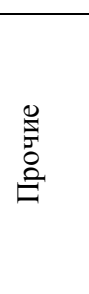 \\
\hline 25-54 года & 11,4 & 14,8 & 26,6 & 6,9 & 5,9 & 4,1 & 4,3 & 3,3 & 2,9 & 2,8 & 2,7 & 2,1 & 0,8 & 11,2 \\
\hline 55-69 лет & 19,2 & 19,2 & 14,8 & 2,0 & 3,9 & 8,2 & 3,4 & 2,2 & 3,7 & 2,1 & 1,7 & 5,9 & 2,6 & 11,0 \\
\hline $\begin{array}{c}\text { Изменение } \\
\text { доли, п.п. } \\
(+/-)\end{array}$ & $+7,8$ & $+4,4$ & $-11,8$ & $-4,9$ & $-2,0$ & $+4,1$ & $-0,9$ & $-1,1$ & $+0,8$ & $-0,8$ & $-1,0$ & $+3,8$ & $+1,8$ & $-0,3$ \\
\hline
\end{tabular}

Источник: расчеты авторов по данным РМЭЗ НИУ ВШЭ.

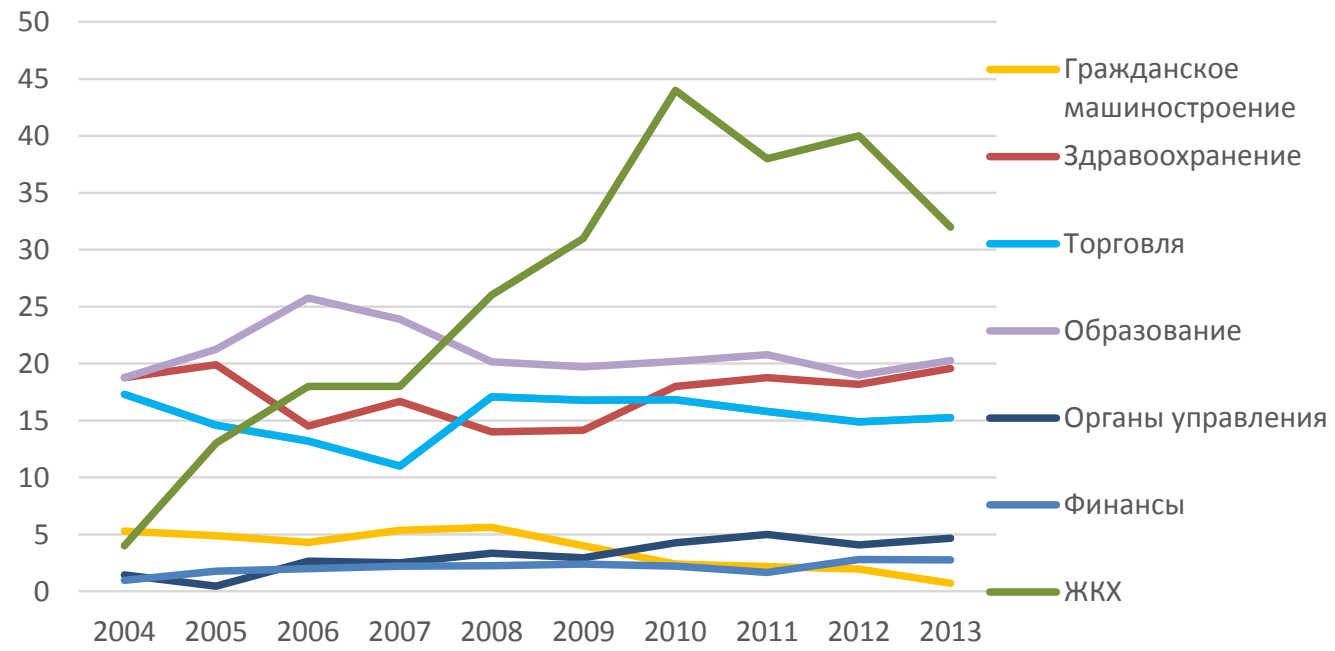

Рисунок 4. Структура занятости женщин в возрасте 55-69 лет по видам деятельности, доля занятых, \%, 2004-2013

Источник: расчеты авторов по данным РМЭЗ НИУ ВШЭ.

Стоит отметить, что отрасли, концентрирующие занятость людей пенсионного возраста, в большинстве своем относятся к государственному сектору. Видимо, пожилым людям проще найти работу именно в бюджетной сфере. В этой связи неудивительно, что по мере снижения роли государства в экономике его роль в занятости пенсионеров снижается куда менее активно (рисунок 5).

Занятость пенсионеров на предприятиях и в организациях с государственным участием может объясняться по-разному. Во-первых, по достижении официального пенсионного возраста работодатель может не спешить расставаться с работниками. Причина - накопленный работниками человеческий капитал, особенно те специфические знания и навыки, которые требуются в этой организации. Но, как справедливо отмечается в статье И. Мальцевой и В. Ляшока [2012], необходимость передачи опыта пожилыми 
работниками, в принципе, существует и в частном секторе. Тем не менее, по мере увеличения возраста пенсионеров они постепенно «вымываются» из частного сектора.

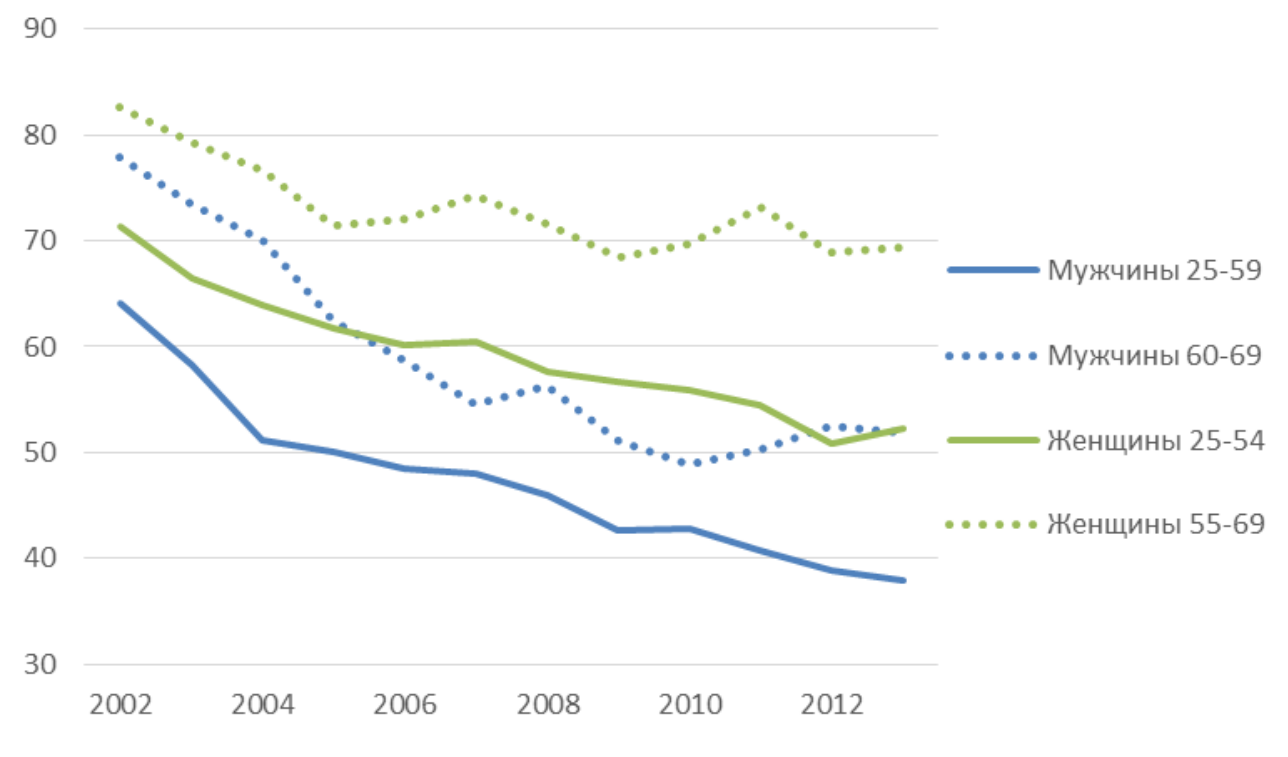

Рисунок 5. Доля занятых на предприятиях и в организациях, полностью или частично принадлежащих государству, по возрастным группам, \%, 2002-2013

Источник: расчеты авторов по данным РМЭЗ НИУ ВШЭ.

Кроме того, не стоит забывать, что работа в бюджетном секторе обладает рядом привлекательных характеристик. Эти рабочие места в большей степени, чем в частном секторе, защищены трудовым законодательством (социальные гарантии, соблюдение режима труда), предполагают работу в более благоприятных условиях и зачастую допускают гибкость в распоряжении рабочим временем. Все это может служить дополнительным стимулом для занятости пенсионеров. Другими словами, пенсионеры могут работать в государственном секторе как вынужденно, поскольку в частном секторе они не востребованы, так и добровольно в силу того, что относительно низкая оплата труда компенсируется неденежными факторами.

\section{ТРАЕКТОРИИ ЗАНЯТОСТИ ПЕНСИОНЕРОВ ПОСЛЕ ДОСТИЖЕНИЯ ПЕНСИОННОГО ВОЗРАСТА}

Как показывает анализ данных РМЭЗ НИУ ВШЭ, изменения в структуре занятости, наблюдаемые при достижении работниками пенсионного возраста, вызваны не перетоком рабочей силы (пенсионеров) из отраслей-доноров в отрасли, наиболее привлекательные для занятости пожилых. Оказывается, более 50\% пенсионеров, занятых в ЖКХ, образовании, здравоохранении, ВПК и науке, работали там же до назначения им пенсии (таблица 5). Именно в этих секторах наиболее толерантно относятся к сохранению занятости лицами, достигшими пенсионного возраста. Другие сферы деятельности, не являющиеся лидерами в отраслевой структуре занятости пенсионеров, характеризуются гораздо меньшей долей пожилых людей, продолжающих работать в отрасли после назначения пенсии. 
Такая ситуация может свидетельствовать о том, что, с одной стороны, работодателям в государственном секторе (образование, здравоохранение, ЖКХ, ВПК, наука) необходимы опыт и знания, накопленные пожилыми работниками. С другой стороны, вероятно, именно работа в этом секторе, предполагая наличие высокой квалификации, не пользуется спросом у более молодых работников в силу относительно невысокой оплаты труда. Пенсионеры же, напротив, могут позволить себе занятость на относительно низкооплачиваемых рабочих местах благодаря тому, что их доходы поддерживает еще и пенсия.

Таблица 5. Доля занятых в отрасли пенсионеров, продолживших работать на том же месте работы после назначения пенсии, в 2013 г., \%

\begin{tabular}{|c|c|c|c|}
\hline & $55-59$ лет & 60-64 года & 65-69 лет \\
\hline $\begin{array}{l}\text { Отрасли-лидеры в привлечении женщин пенсионного возраста } \\
\text { (первая четвертка в отраслевой структуре занятости пожилых } \\
\text { женщин) }\end{array}$ & 72,4 & 48,4 & 45,9 \\
\hline Остальные отрасли, где заняты женщины пенсионного возраста & 16,8 & 9,9 & 2,2 \\
\hline $\begin{array}{l}\text { Отрасли-лидеры в привлечении мужчин в пенсионном возрасте } \\
\text { (первая четвертка в отраслевой структуре занятости пожилых } \\
\text { мужчин) }\end{array}$ & - & 53,6 & 50,0 \\
\hline Остальные отрасли, где заняты мужчины пенсионного возраста & _ & 17.0 & 4.1 \\
\hline
\end{tabular}

Таблица 6. Топ-10 профессий мужчин-пенсионеров, сохранивших рабочее место или поменявших его в пенсионном возрасте, \% от общей численности сохранивших рабочее место/поменявших рабочее место, 2013

\begin{tabular}{l|r|l|r}
\hline Продолжившие работать на том же рабочем & & $\begin{array}{l}\text { Сменившие работу после назначения } \\
\text { пенсии }\end{array}$ & \\
\hline Сесте, что и до назначения пенсии & 10,0 & Сторож & 23,9 \\
Инженер & 5,0 & Дворник & 6,4 \\
Автослесарь & 4,0 & Директор небольшого предприятия & 3,7 \\
Начальник отдела НR & 3,0 & Трубоукладчик & 3,7 \\
Начальник других отделов & 3,0 & Оператор токарного станка & 3,7 \\
Директор предприятия & 3,0 & Водитель грузового автомобиля & 3,7 \\
Врач-специалист & 3,0 & Преподаватель & 2,8 \\
Механик & 3,0 Электрик & 2,8 \\
Оператор судового котла & 3,0 Автослесарь & 2,8 \\
Водитель общественного транспорта & 3,0 & Водитель & 2,8 \\
\hline \multicolumn{2}{c}{ Источник: расчеты авторов по данным РМЭЗ НИУ ВШЭ. }
\end{tabular}

Начавшие работать на новом месте работы после достижения пенсионного возраста гораздо чаще работают на низкоквалифицированных позициях (таблицы 6, 7) и без оформления трудового договора (таблица 8). При этом среди объяснений нежелания работать официально примерно равную долю ответов составляют нежелание работодателя, нежелание работника и обоюдное нежелание официально оформлять занятость.

Таким образом, значительная доля занятых неквалифицированным трудом пенсионеров свидетельствует об их готовности работать даже на низкооплачиваемых рабочих местах, часто без официального оформления, чтобы обеспечить пусть небольшую, но прибавку к пенсии. Для работодателей экономия на налогах и низкие зарплатные ожидания также повышают привлекательность найма пенсионеров на рабочие места, не требующие квалификации. 


\section{Таблица 7. Топ-10 профессий женщин-пенсионеров, сохранивших рабочее место или} поменявших его в пенсионном возрасте, \% от общей численности сохранивших рабочее место/поменявших рабочее место, 2013

\begin{tabular}{|c|c|c|c|}
\hline $\begin{array}{l}\text { Продолжившие работать на том же рабочем } \\
\text { месте, что и до получения пенсии }\end{array}$ & & $\begin{array}{l}\text { Сменившие работу после назначения } \\
\text { пенсии }\end{array}$ & \\
\hline Преподаватель в школе & 5,1 & Уборщик & 18,2 \\
\hline Старшая медсестра & 5,1 & Билетный контролер & 9,8 \\
\hline Уборщицы в гостиницах, самолетах и т.д. & 5,1 & Продавец & 7,6 \\
\hline Бухгалтер & 4,8 & Консьержка & 5,5 \\
\hline Продавец & 4,8 & Сиделка & 2,9 \\
\hline Воспитатель в детском саду & 3,4 & Др. специалисты в области образования & 2,6 \\
\hline Др. специалисты в области образования & 3,1 & Преподаватель в школе & 2,2 \\
\hline $\begin{array}{l}\text { Преподаватель высшего и среднего } \\
\text { профессионального образования }\end{array}$ & 2,8 & Главный бухгалтер & 2,2 \\
\hline Главный бухгалтер & 2,8 & Помощник воспитателя & 2,2 \\
\hline Сиделка & 2,8 & Дворник & 2,2 \\
\hline
\end{tabular}

Источник: расчеты авторов по данным РМЭЗ НИУ ВШЭ.

Таблица 8. Доля неформально занятых среди работников пенсионного возраста в 2013 г., \%

\begin{tabular}{l|c|c}
\hline & Продолжает работать на том же рабочем \\
& месте, что и до назначения пенсии & $\begin{array}{c}\text { Устроился на работу после } \\
\text { назначения пенсии }\end{array}$ \\
\hline Женщины 55-69 лет & 2,5 & 13,3 \\
$55-59$ лет & 3,6 & 8,1 \\
Мужчины $60-69$ лет & 1,1 & 12,9 \\
$60-64$ лет & 1,3 & 12,7 \\
\hline
\end{tabular}

Источник: расчеты авторов по данным РМЭЗ НИУ ВШЭ.

Можно сделать вывод, что для сохранения экономической активности в пенсионном возрасте есть две возможности, во многом предопределяемые сферой занятости до достижения пенсионного возраста. Если до наступления официального пенсионного возраста человек был занят в одной из организаций бюджетной сферы, то наиболее вероятно, что он сохранит свое место работы и профессию в пенсионном возрасте. Напротив, людям, трудившимся до достижения пенсионного возраста в любой другой отрасли, с большей вероятностью придется менять работу, теряя и в квалификации, и в официальном характере занятости. Однако стоит отметить, что место работы и профессия в пенсионном возрасте могут определяться и осознанным желанием самого индивида найти себе «более спокойное» место работы (так называемый дауншифтинг). Этот мотив также может быть причиной большего распространения работы, не требующей высокой квалификации, и неофициального характера занятости среди сменивших работу после достижения пенсионного возраста.

\section{НЕФОРМАЛЬНАЯ ЗАНЯТОСТЬ}

Согласно методологии Росстата, под неформальной занятостью понимается занятость на предприятии, у которого отсутствует государственная регистрация в качестве юридического лица. При работе с данными РМЭЗ НИУ ВШЭ мы под неформальной занятостью понимали отсутствие официального оформления трудовой деятельности в организации/предприятии, либо работу на частное лицо, которое официально не 
зарегистрировано в качестве индивидуального предпринимателя (по мнению респондента), либо случайные заработки, которые рассматриваются респондентом как регулярный доход, но не оформлены официально.

Такие данные доступны для анализа с 2005 г. (за исключением 2008 г., таблица 9). Неформальная занятость действительно больше распространена среди работников пенсионного возраста. При этом в периоды низкого экономического роста неформальная занятость увеличивалась. Стоит отметить и ее рост в 2012-2013 гг. Учитывая, что темпы экономического роста в 2013 г. начали замедляться, рост неформальной занятости может свидетельствовать об усложнившемся доступе лиц пенсионного возраста на официальный рынок труда.

Таблица 9. Доля неформально занятых, \% от всех занятых в данной половозрастной группе

\begin{tabular}{l|r|r|r|r|r|r|r|r}
\hline & 2005 & 2006 & 2007 & 2009 & 2010 & 2011 & 2012 & 2013 \\
\hline Мужчины, 25-59 лет & 7,8 & 10,0 & 7,4 & 7,6 & 8,0 & 7,9 & 9,0 & 8,8 \\
Мужчины, 60-69 лет & 9,3 & 6,9 & 6,2 & 9,1 & 6,9 & 8,5 & 8,4 & 10,4 \\
Женщины, 25-54 года & 3,9 & 6,5 & 4,8 & 6,4 & 4,5 & 5,2 & 6,6 & 6,4 \\
Женщины, 55-69 лет & 7,1 & 9,8 & 9,4 & 11,9 & 6,8 & 7,2 & 9,8 & 12,2 \\
\hline
\end{tabular}

Источник: расчеты авторов по данным РМЭЗ НИУ ВШЭ.

\section{ЧАСТИЧНАЯ ЗАНЯТОСТЬ И САМОЗАНЯТОСТЬ}

В последние годы в развитых странах одним из факторов роста экономической активности пожилых выступает повышение гибкости рынка труда - расширение возможностей для неполной занятости и самозанятости пенсионеров [Сонина 2015]. Для российских пенсионеров также характерна большая распространенность частичной занятости. Так, в 2013 г. неполную рабочую неделю (менее 35 рабочих часов) имели 18\% из всех занятых мужчин пенсионного возраста против 4,6\% мужчин в возрасте 25-59 лет и 24,4\% занятых женщин пенсионного возраста против 10\% в возрасте 25-54 лет. Однако, исходя из динамики доли занятых неполную рабочую неделю, мы не можем утверждать, что люди пенсионного возраста стали чаще прибегать к такой форме занятости. Как доля работающих в режиме неполной занятости, так и средняя продолжительность рабочей недели у пенсионеров остаются примерно одинаковыми в рассматриваемый период 2002-2013 гг., немного колеблясь из года в год.

В то же время доля самозанятых в современной российской экономике имеет устойчивую тенденцию к снижению, особенно среди мужчин (рисунок 6). Основное снижение пришлось на период до 2008 г. Для пенсионеров минимум самозанятости пришелся как раз на 2008 г. С 2008 г. доля занятых на предприятии или в компании, владельцем которого является индивид, сохраняется на уровне 2-3\% для пенсионеровмужчин и на уровне $2 \%$ для пенсионеров-женщин. Стоит отметить, что столь небольшое распространение занятости на собственном предприятии практически не отличается от оценок ее распространения среди населения в основном трудоспособном возрасте: около $4 \%$ для мужчин и $2 \%$ для женщин. Этим фактом Россия сильно отличается от большинства развитых стран, где в последние годы темпы роста самозанятости и ее распространённости 
среди лиц пенсионного возраста значительно росли. В частности, это стало одним из главных факторов повышения экономической активности пожилых в Австралии, Канаде, Великобритании [Thompson 2007; Kennedy, Costa 2006]. Так, в Канаде самозанятыми являются 40\% работающих пожилых (старше 65 лет) и лишь 14\% работников в возрасте 25 54 лет [Macewen 2012]. Та же картина характерна и для Великобритании. Темпы роста самозанятости среди работников старше 70 лет в 2002-2012 гг. достигли 88\%, среди работников 65-69 лет - 49\%, тогда как среди индивидов 24-49 лет - 12\% [Bell, Rutherford 2013]. В результате самозанятыми являются 32\% работающих пожилых против 13\% населения, не достигшего пенсионного возраста [Office for national statistics 2012].

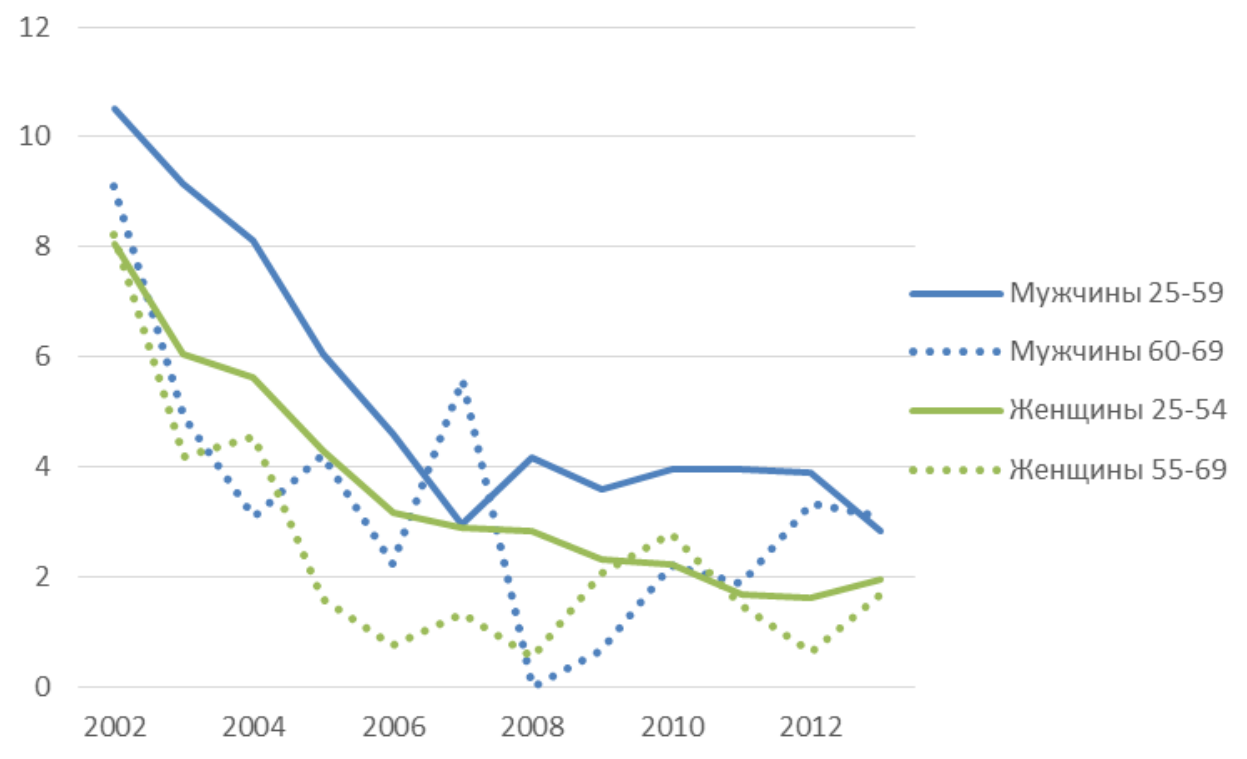

Рисунок 6. Доля самозанятых среди всех занятых в данной половозрастной группе, \%

Источник: расчеты авторов по данным РМЭЗНИУ ВШЭ.

\section{Выводы}

Как показывают данные РМЭЗ, рост экономической активности пожилых россиян в последние годы был обеспечен «молодыми» пенсионерами. Как и в большинстве развитых стран, наибольший вклад в рост экономической активности пенсионеров внесли женщины. Однако на этом аналогии с динамикой экономической активности пожилых в развитых странах заканчиваются.

Анализ микроданных позволяет увидеть, что динамика экономической активности пожилых является производной от возможностей занятости в таких сферах деятельности, как образование, здравоохранение, наука, ВПК и ЖКХ, то есть там, где преобладает государство. Так, доля занятых в этих секторах среди всех работающих мужчинпенсионеров увеличилась с 40\% в 2004 г. до более 55\% в 2013 г., для женщин характерны аналогичные изменения - рост с 60 до 67\%. Стоит отметить, что работу в названных секторах экономики сохраняют, как правило, те, кто уже трудился в «нужной» отрасли до назначения пенсии. Человек, меняющий работу и сферу занятости после назначения 
пенсии, вероятнее всего устраивается на место, не требующее высокой квалификации, часто без официального оформления трудовых отношений.

В отличие от развитых стран повышение гибкости рынка труда также не характерно для России. Ни частичная занятость, ни самозанятость не стали факторами роста экономической активности пенсионеров в последние годы.

Анализ тенденций и характеристик занятости людей пенсионного возраста в России показывает, что в будущем можно ожидать дальнейшего роста их экономической активности по мере вступления в группу пенсионеров относительно молодых и многочисленных возрастных когорт. Однако для эффективного использования потенциала этих работников, хорошо образованных и обладающих современными навыками, государству необходимо разрабатывать специальную политику, поощряющую разнообразные и гибкие формы занятости, программы переквалификации, возможности самозанятости и др. В противном случае растущая армия работающих пенсионеров будет не только пополнять штаты государственных учреждений, но и способствовать дальнейшему расширению неформальной занятости в российской экономике.

\section{ЛИТЕРАТУРА}

Госкомстат России (2002). Экономическая активность населения России. М.: 190.

Колосницына М., М. Герасименко (2014). Экономическая активность в пожилом возрасте и политика государства // Вопросы государственного и муниципального управления. №4: 47-68.

Малева Т., О. Синявская (2008). Нужно ли повышать занятость пенсионеров? // Demoscop Weekly. URL: http://www.demoscope.ru/weekly/2008/0341/tema05.php (дата обращения: 25.12.2014).

Мальцева И.О., В.Ю. Ляшок (2012). Пожилое население России на рынке труда в 2000-е годы // В кн.: Вестник Российского мониторинга экономического положения и здоровья населения НИУ ВШЭ (RLMS-HSE) / Отв. ред.: П. М. Козырева. Вып. 2. М.: Издательский дом НИУ ВШЭ: 95-110.

Росстат (2014). Экономическая активность населения России. М.:143.

Синявская О. (2011). История пенсионной реформы в России. История новой России. Очерки, интервью: в 3 т. / под общ. ред. П.С. Филиппова. Т. 3. СПб.: Норма: 142-201.

Сонина Ю. (2015). Экономическая активность людей пожилого возраста в России: вслед за мировым трендом? // Вопросы статистики. № 5: 48-58

Федеральный закон от 31 июля 1995 г. № 119-Ф3 «Об основах государственной службы Российской Федерации".

Федеральный закон от 2 июля 2013 г. № 162-Ф3 «О внесении изменений в Закон Российской Федерации «О занятости населения в Российской Федерации» и отдельные законодательные акты Российской Федерации».

Bell D., A. Rutherford (2013). Older workers and working time // The journal of the economics of ageing. Vol. 1-2: 28-34. 
Kennedy S., A. Costa (2006). Older men bounce back: the re-emergence of older male workers.URL:

http://archive.treasury.gov.au/documents/1190/HTML/docshell.asp?URL=04_men.asp (дата обращения: 25.12.2014).

MacEwen A. (2012).Working after age 65. What is at stake? Alternative federal budget 2012 technical paper. Canadian Centre for policy alternatives. URL:

https://www.policyalternatives.ca/publications/reports/working-after-age-65 (дата обращения: 25.12.2014).

Office for National statistics (2012). Older workers in the labour market. URL: http://www.ons.gov.uk/ons/dcp171776_267809.pdf (дата обращения: 25.12.2014).

Thompson T. (2007). The transition of older Australian workers to full and partial retirement. University Melbourne. URL:

http://fbe.unimelb.edu.au/_data/assets/pdf_file/0010/802828/1005.pdf (дата обращения: 25.12.2014). 


\section{PENSIONERS ON THE RUSSIAN LABOUR MARKET: TRENDS OF ECONOMIC ACTIVITY IN PENSION AGE *}

\section{YULIYA SONINA, MARINA KOLOSNITSYNA}

Yuliya V. Sonina. National Research University Higher School of Economics. E-mail: juliasonina@hse.ru. Marina G. Kolosnitsyna. National Research University Higher School of Economics, Russia.

DATE RECEIVED: March 2015.

Population ageing is forcing researchers throughout the world to study more closely the economic activity of pensioners. In Russia in the last few years pensioner employment has demonstrated significant growth, while economic activity of the working age population has remained stable. This fact requires further investigation. One of the sources that can shed light on the trends in pensioners' employment activity is data from The Russia Longitudinal Monitoring Survey (RLMS-HSE).

In this paper we use data from the Russian Statistical Office (Rosstat) and RLMS-HSE to analyze the trends of older people's employment activity from the statutory age of retirement (55 for women and 60 for men) until age 70. We show that the recent increase in economic activity was typical for Russian pensioners of all age groups, but the highest growth was recorded for females 60-64 years old. The paper also reveals that among all working pensioners the share of those employed in education, healthcare, science, housing services, The ministry of internal affairs and the military-industrial sector-economic sectors where the role of the state is predominant - has increased for the period under review. Hence the most popular career options for those working at pension age are either to keep their previous job in the above-mentioned industries, or to change jobs, often for a less demanding position and/or informal employment. Unlike developed countries, the increase of economic activity of Russian pensioners has not been driven by increased flexibility of the labor market. Neither the share of self-employed nor the share of part-time employed pensioners increased in the period under study.

Key words: pensioners, older people, employment, economic activity, Russia.

* THE STUDY WAS COMPLETED WITHIN THE PROJECT «OLDER PEOPLE OPPORTUNITIES, SOCIO-ECONOMIC DETERMINANTS OF ACTIVE ageing, and public POlicies» Funded by the Basic Research Program at the National Research University HigheR SCHOOL OF ECONOMICS IN 2015.

\section{REFERENCES}

Bell D., A. Rutherford (2013). Older workers and working time // The journal of the economics of ageing. Vol. 1-2: 28-34

Goskomstat (2002). Economic activity of Russian population. M.:143.

Kennedy S., A. Costa (2006). Older men bounce back: the re-emergence of older male workers. URL: http://archive.treasury.gov.au/documents/1190/HTML/docshell.asp?URL=04_men.asp (accessed: 25.12.2014).

Kolosnitsyna M.G., M.A. Gerasimenko (2014). Ekonomicheskaya aktivnost v pozhilom vozraste I politika gosudarstva [Labour force participation of older citizens and public policy]. Public Administration Issues, n. 4, pp. 47-68 (in Russian).

Macewen A. (2012). Working after age 65. What is at stake? Alternative federal budget 2012 technical paper. Canadian Centre for policy alternatives. URL: https://www.policyalternatives.ca/publications/reports/working-after-age-65 (accessed: 25.12.2014). 
Maleva T., O. Sinyavskaya (2008). Nuzhno li povushatzanyatostpensionerov? [Is it necessary to increase the pensioners' employment?] // Demoskop Weekly. URL:

http://www.demoscope.ru/weekly/2008/0341/tema05.php (accessed: 25.12.2014).

Maltseva I.O., V.Yu. Lyashok (2012). Pozhiloe naselenie Rossii na runke truda v 2000-e gody [The older peopleon the Russian labour market in 2000s] // In bulletin of Russian Longitudinal Monitoring Survey / Publ.editor P.M. Kozyreva. №2. NRU-HSE: 95-110.

Office for National statistics (2012). Older workers in the labour market. URL: http://www.ons.gov.uk/ons/dcp171776_267809.pdf (accessed: 25.12.2014).

Rostat (2014). Economic activity of Russian population. M.:143.

Sinyavskaya O. (2011). Istoriya pensionnoi reform v Rossii. Istoriya novoi Rossii [History of Russian pension reform. History of new Russia]. Essays and interviews in 3 volumes / Editor P.S. Filippova. Volume № 3. SP.: Norma: 142-201.

Sonina Y. (2015). Economisheskaya activnost lyudei pozhilogo vozrasta v Rossii: vsled za mirovym trendom? [Labor force participation of the elderly in Russia: following the global trend?] // Questions of statistics. № 5: 48-58

Thompson T. (2007). The transition of older Australian workers to full and partial retirement. University Melbourne. URL:

http://fbe.unimelb.edu.au/_data/assets/pdf_file/0010/802828/1005.pdf (accessed: 25.12.2014). 